\title{
FORD MADOX FORD
}





\section{FORD MADOX FORD}

THE ESSENCE OF HIS ART

by R. W. Lid

University of California Press

Berkeley and Los Angeles 1964 
UNIVERSITY OF CALIFORNIA PRESS

BERKELEY AND LOS ANGELES, CALIFORNIA

CAMBRIDGE UNIVERSITY PRESS

LONDON, ENGLAND

(C) 1964 BY THE REGENTS OF THE UNIVERSITY OF CALIFORNIA

LIBRARY OF CONGRESS CARD CATALOG NO. 64-20994

PRINTED IN THE UNITED STATES OF AMERICA 
For Kenneth Millar 
